\title{
ANGIOMA OF THE SKIN OF A COW.
}

\author{
By A. M. Trotter, M.R.C.V.S., Glasgow.
}

SoME time ago my attention was directed to a pedunculated growth of the skin covering the right mamma of an aged Ayrshire cow. It was situated on the posterior aspect, several inches below the junction of the mamma with the thigh. It was the size of a pigeon's egg. The skin which covered it was thin, of a bluish colour, and showed comparatively few hairs. The tumour was painless, soft, non-pulsating, and it bled profusely on being roughly handled. The blood, as it escaped, flowed over the skin of the mamma, and dropped on the ground, or, if milking operations were being performed, in the vicinity of, or into the milk pail. The tumour was removed by écraseur.

No reliable clinical history was obtainable.

On microscopical examination, the tumour was found to be composed of a more or less delicate network of fibrous tissue. The spaces formed by this network varied greatly in size. They were, as a rule, circular, oblong, or elongated according to the angle at which the vessel was cut. Some, however, were irregular in shape owing to the trabeculæ becoming ruptured. These spaces, which were filled with blood, and lined by flattened, spindle-shaped, endothelial cells possessing one or more round nuclei, were apparently merely dilated blood vessels. The trabeculæ were in some places composed only of the two layers of endothelial cells lining the respective spaces, but more frequently these cells were supported by an intermediate layer of fibrous tissue. Numerous young connective tissue corpuscles were present between or in the fibres composing the trabecula. The tissues in the vicinity of the base of the tumour showed a dense cellular infiltration. This was evidently due to some inflammatory process - a complication which occasionally occurs in these tumours.

\section{DERMOID CYST IN A COW.}

By the Same.

WHILST making a post-mortem examination on an aged Irish cow, a growth was discovered on manipulation under the mastoido-humeralis, in the lower part of the cervical region. On dissection, it was found to be situated in close contiguity, but inferior to the right prescapular group of lymphatic glands. It was loosely attached by fibrous tissue to the inner surface of the mastoido-humeralis and to the adjacent adipose tissue. It was irregularly circular in shape, and had the appearance of a sphere flattened laterally through pressure. It measured $6.4 \mathrm{~cm}$. in diameter, and $3 \mathrm{~cm}$. in thickness. It was firm and non-elastic in consistency.

The growth on section was seen to be a dermoid cyst.

The cyst wall measured $\mathrm{I} \mathrm{mm}$. in thickness, and appeared on macroscopical examination to be structureless. The inner surface was white, and sparsely studded with hairs. The latter were white, and finer than those usually found on cattle. In some instances they attained two inches in length. The contents of the cyst were shed dermoid 